\title{
THE EFFECT OF TAX INFORMATION SYSTEMS AND TAXATION SANCTIONS TOWARDS TAXPAYER COMPLIANCE WITH CAFE OWNERS OF SME (SMALL- MEDIUM ENTERPRISE) TAXES
}

\author{
Magfirah Di'iznania Armin \\ Universitas Padjajaran, Indonesia \\ Magfirah19001@gmail.unpad.ac.id
}

\begin{abstract}
Taxes are among the highest income generated by the state originating from within the country. However, most taxpayers did not understand how and what the tax information system is like in Indonesia and how tax Sanctions are applied. So that in this case it tends to reduce taxpayer compliance. This study aims to determine the effect of tax information systems and tax sanctions on taxpayer compliance. This research method is quantitative research using primary data. Determination of the sample using purposive sampling. The sample in this study consisted of 26 respondents who owned cafes in the city of Palu. The analytical method used is descriptive and statistical analysis. The results of this study indicate that partially the tax information system has a positive and significant effect on taxpayer compliance. However, tax sanctions are positive but did not effect, that meaning tax sancations are not significant to taxpayer compliance, because they have a t-calculated value of less than 0,05 with a correlation value of $2,3 \%$ on taxpayer compliance.
\end{abstract}

Keywords: Tax Information system, Tax sanctions, Taxpayer compliance.

\section{INTRODUCTION}

In the Indonesian economy, taxes have a very important role, including in the APBN, taxes are one of the largest sources of income. It is noted that $70 \%$ of Indonesia's State Budget is financed by taxes. In this case, good tax information friendly will facilitate taxes in making tax payments, where taxpayers will provide knowledge about taxes, such as reporting and payments so that this will make it easier for taxes to be more obedient in carrying out their obligations as taxpayers. In Indonesia, there were 6 sectors that were the biggest contributors to tax revenue in the first half of 2019. In this case, there were positive growth but some were negative. In 2020, tax revenue will be a challenge due to the slowdown in economic activity as a result of the Covid-19 pandemic which has not only hit Indonesia. As a result of this, the realization of tax in 2020 in the first semester was recorded at IDR 531.7 trillion or $44 \%$, almost all major types of taxes this year experienced a contraction, wherein this non-oil and gas PPh also fell $10.1 \%$ and PPnBM decreased $10.7 \%$, PBB and other taxes decreased by $18.89 \%$, and the higher the reduction was the Oil and Gas PPh by $40.1 \%$. The contraction in tax revenue did not only come from weak economic growth but also from the provision of incentives in the context of the impact of Covid-19 which was given to the public or burdens in the business world. One of the businesses affected by Covid-19 is a cafe. Where it is known that cafes are one of the small and medium enterprises (MSMEs) that generate the largest tax revenue. With the very rapid growth in the cafe business sector, there are also more potential depositors, but this is not in line with what is certain that taxes are proven by submitting taxpayers whose business tax at the tax office is recorded 80 taxpayers whose business tax is in 2020 Good owner hotels, restaurants, cafes 
and restaurants where this is not in accordance with the existing cafes and restaurants in the city of Palu. Lack of awareness to pay tax obligations is still lacking and lack of knowledge regarding tax sanctions that will be given by taxpayers violating their tax obligations. Therefore, by providing knowledge about tax information systems and tax sanctions given to taxpayers, it will provide taxpayers in carrying out their tax activities to be able to carry out and provide direction for taxpayers in carrying out their tax payments. In this case, it has been regulated in Law number 28 of 2007 concerning providing and services for taxpayers. In 2020, there are challenges that the government is not only dealing with economic problems but also in helping to raise awareness of taxpayers so that they are obedient in paying their taxes. According to (Siti Kurnia Rahayu 2013). Compliant taxpayers are taxpayers who are obedient and fulfill and carry out tax obligations in accordance with taxation regulations. Therefore, KPP Pratama Palu has implemented a new information system so that it is expected that taxpayers will carry out their tax activities. However, what happens is that there are still less taxpayers who are not alert as to what the current tax information system is right now and in this case it tends to reduce taxpayers, there are other factors that are reduced by taxpayers, namely taxpayers. In this case, there are still many who are negligent in the tax sanctions given. According to (Jatmaiko Agus Nugroho 2006) Taxpayers will comply with taxes, taxpayers will be more detrimental to the implementation of strict tax sanctions to control taxpayer control, taxpayers will obey taxpayers who think that tax obligations are very detrimental. According to (Hardiningsih 2011) there are factors that influence tax-affecting regulations caused by awareness of paying taxes, knowledge of taxation perceptions of the effectiveness of the taxation system and quality of service.
This is also regulated in Law no. 28 of 2007 concerning the general provisions of taxation (UU KUP) where there are 2 sanctions that are given administrative sanctions and criminal sanctions. It is hoped that with the sanctions given by taxpayers, they can be more obedient in obeying tax regulations. Therefore, it is necessary to provide education on tax obligations that are subject to taxation to raise awareness of taxpayers themselves.Pajak according to law No. 16 of 2009 article 1 paragraph (1) regarding general provisions and procedures for taxation, tax is a mandatory contribution to the state that is owed by an individual or entity which in this case is compelling, based on law with no compensation directly and used for the needs of the state for the greatest prosperity of the people. Meanwhile, Prof. Dr. Rochmat Seomitro, SH in the book Mardiasmo (2016), namely: "Taxes are people's contributions to the state treasury based on the law (which can be enforced) without receiving lead services (counterparts) which can be directly demonstrated and which are used to pay general expenses" Definition of UMKM Based on Law no. 20 of 2008 Article 1, states that a micro business is a productive business owned by individuals and / or individual business entities that meet the criteria of a micro business as stipulated in the law. Meanwhile, a small business is a business in the productive economy, where this business is independent, and is carried out by individuals who are not a subsidiary or branch of a company that is owned, controlled or is part of a medium or large business, either directly or indirectly. that meets the criteria of a small business. Understanding Café The word Café comes from French which means coffee. According to (Budiningsih 2009) cafe or cape is a small restaurant outside the hotel which has limited food choices and does not sell high alcoholic drinks, but drinks such as beer, soft drinks, tea, coffee, cigarettes, snacks, etc. . Cafes are also 
one type of business that is now in great demand by entrepreneurs. Tax Information System according to (O'Brien 2016) information systems are a combination of people, hardware, software, communication networks, data resources, and policies and procedures for storing, retrieving, changing and disseminating information within an organization. In addition, according to (Yakub 2012), the information system is a regular, combination of people, hardware, software, communication networks, and resources that collect, modify and disseminate information in an organization. The tax information system is a document of funds or tax data in digital form contained in the tax information system application at the Directorate General of Taxes, including its vertical organizational units. according to the regulation of the director general of taxes Number: per160 / PJ / 2006, the Tax Information System (SIP) is an information system in tax administration within the tax directorate general's office using hardware and software linked in a local network. Tax Sanctions according to (Mardiasmo 2011) tax sanctions are a guarantee that the provisions of laws and regulations (taxation norms) will be obeyed / obeyed / obeyed. Where tax sanctions are a means of deterrence (preventive) so that taxpayers do not violate tax laws. According to (Siti Masruroh and Zulaikha 2013) in his research, he said that if you see tax sanctions that will be more detrimental to him, taxpayers will comply with making tax payments. The application of sanctions like this aims to provide a deterrent effect on taxpayers who violate tax regulations so that the voluntary compliance of taxpayers will be created in exercising their tax rights and obligations. Taxpayer Compliance According to Chaizi Nasucha in Siti Kurnia Rahayu (2013: 139), the definition of taxpayer compliance is the compliance of taxpayers in registering themselves, compliance to re-deposit
SPT, compliance in calculating and paying taxes owed, compliance in paying arrears. Meanwhile, according to James and Alley dal Timbul Hamonangan (2012: 84) states that: "Tax compliance in its most simple from is usually cast in terms of the degree version relate which taxpayer complies with the tax law"

Hypothesis

The research hypothesis is based on literature review, namely:

$\mathrm{H} \mathrm{1}$ : application of tax information system to taxpayer compliance of cafe owners UMKM

$\mathrm{H} 2$ : understanding of tax sanctions on the compliance of UMKM taxpayers of cafe owners

\section{METHODS}

This research method uses quantitative research using a correlation approach. Meanwhile, according to (Sugiyono 2013), the quantitative research method is a research method based on the positivism philosophy, which is used to research on certain populations or samples, and in general the sampling technique is carried out randomly with data collection tools using quantitative data analysis research instruments. statistic with the aim that is to test the hypothesis that has been set. Meanwhile, according to (Zaenal Arifin 2011) the correlation research method was chosen to study the relationship between two or more variables, namely where the relationship between variations in one variable and variations in variables, and in general, correlation research does not control or manipulate variables. The data used in this study is quantitative data, quantitative data is non-verbal data, that is, data can be measured and calculated directly in the form of numbers. In this study, namely, the number of taxpayers (WP) who have a cafe business in the city of Palu and the results of the questionnaire. Sources of data in this study use primary data in the form of questionnaires given to respondents and data about the general 
description of the institutions obtained from within. This research uses the observation unit. The population in this study is an individual taxpayer (WPOP) who owns a cafe business in Palu City. And the sampling technique in this research is using purposive withdrawal method, namely sampling using special criteria for the sample. The criteria used in this sample are individual taxpayers who have registered cafe businesses at the KPP Pratama tax service office in Palu City and the number of respondents in this study were 26 respondents. The instrument testing technique in this study uses validity and reliability tests. According to (Ghozali Imam 2011) the validity test is used to determine whether the research questionnaire is valid or not. This test is done by comparing the calculated $r$ coefficient and the $r$ table coefficient. Where if the calculated $r$ value is greater than $r$ table then the item is valid. Conversely, if $r$ count is smaller than $r$ table, it means that the research item is not valid for use. and reliability testing is used to measure a research questionnaire which is an indicator of the construct or variable. Meanwhile, according to (Ghozali Imam 2011), a questionnaire is said to be reliable if a person's answer to the question is consistent or stable over time. This test is done by calculating the amount of Cronbach's alpha value of each instrument of a variable and a variable is said to be reliable if the value of Cronbach's alpha is more than 0.60. In this study also carried out classical assumption tests, hypothesis testing and determination with regression equations which are formulated based on the developed hypothesis, namely:

$$
\mathrm{Y}=\mathrm{a} \beta 1 \mathrm{X} 1+\beta 2 \mathrm{X} 2+\ldots+\mathrm{b}_{\mathrm{n}} \mathrm{X}_{\mathrm{n}}
$$

Information:

$\begin{array}{ll}\mathrm{Y} & =\text { Taxpayer compliance } \\ \mathrm{A} & =\text { constant }\end{array}$ $\beta 1 \mathrm{X} 1=$ tax information system

regression coefficient

$\beta 2 X 2=$ Tax sanctions regression coefficient

$\varepsilon=$ Error

\section{RESULTS AND DISCUSSION}

This research was conducted in a cafe in the city of Palu which will be randomly selected according to the sample of this study. The results of data collection in this study were carried out with this research sample. The results of data collection in this study were conducted using a questionnaire. This research was conducted at cafes in the city of Palu, using a purposive sampling technique, totaling 26 cafes in Palu registered at the Palu city tax office, where the questionnaires were distributed directly to 26 cafes addressed to the cafe owners. The questionnaires that were distributed were 26 copies, none of which were declared invalid because all questionnaires were returned according to the number of respondents and had been filled in completely by the respondents, so that the questionnaires that could be processed were 26 copies.

\section{Research Instrument Testing Validity Testing}

The validity test is conducted to measure the validity of the questionnaire in the study. Testing is done by comparing the calculated $r$ coefficient with the critical $r$ coefficient. If $r$ count is greater than $r$ critical indicates the item is valid. Conversely, if $r$ count is less than critical $r$, it means that the item is not valid for use. With the number of respondents as many as 26 people, then the critical $r$ is used according to the criteria of 0.3 . Test the validity of all statement items that represent each variable in this study using SPSS for windows version 24.0 for the tax information system variable, there are 12 statement items that were tested for validity. Based on the test results on the tax information system variable, it is 
stated that all measured items are valid because they have $r$ count greater than critical $r$. for the tax sanction variable which is the second variable studied with the 5 statement items proposed in this study are declared valid with $r$ count greater than the critical $r$ value. Furthermore, the taxpayer compliance variable with 10 statement items submitted in the research questionnaire with validity test results is valid because it has $r$ count greater than the critical $r$ value.

\section{Reliability Test}

All research instruments in this study were declared valid, then reliability testing was carried out to test the reliability of the research instrument. This test is done by calculating how much Cronbach's alpha value of each instrument from a variable. A variable is said to be reliable if the magnitude of Cronbach's alpha is more than 0.60 (Ghozali, 2011). The reliability test in this study used the computer assistance program SPSS for windows version 24.0 to perform $X$ and $Y$ statistical tests with Cronbach's alpha value $>0.6$ so that the data used in this study were reliable.

\section{Classic assumption test Normality test}

To find out whether the regression model confounding or residual variables have a normal distribution or do not have a normal distribution, a normality test is performed. Where in this case, normality detection is done by looking at the distribution of data (points) on the diagonal axis with a graph. The results of the probability plot test show that the points spread around the diagonal line and the distribution follows the diagonal line, so it can be concluded that the requirements for normality can be met and all variables in this study are normally distributed. The detection can be fulfilled and all variables in this study are normally distributed. Normality detection can be done by looking at the distribution of data (points) on the diagonal axis of the graph. The results of the probability plot test show that the points spread around the diagonal line and the distribution follows the diagonal line, so it can be concluded that the requirements for normality can be met and all variables in this study are normally distributed.

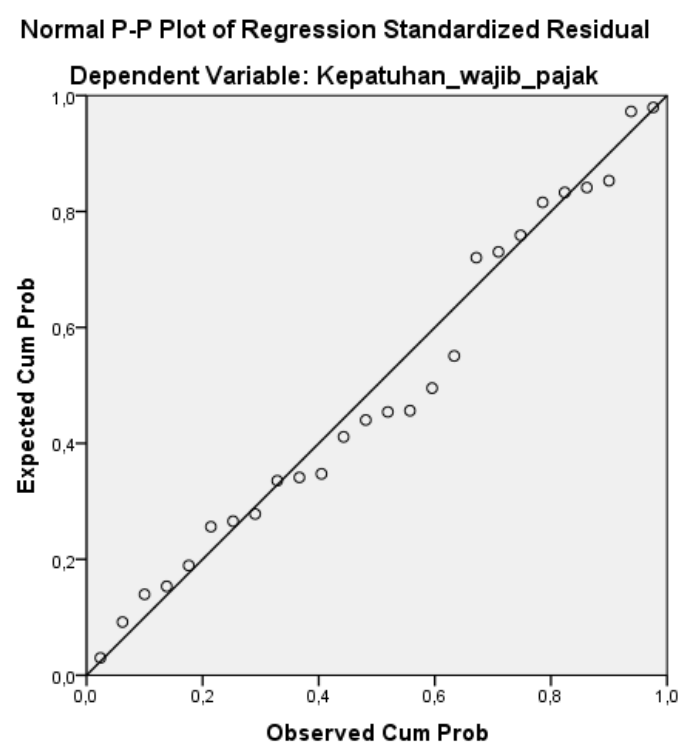

Figure 2: Probability Plot Test Results 


\section{Multicolonierity Test}

Table 1. Multicolonierity Test Results

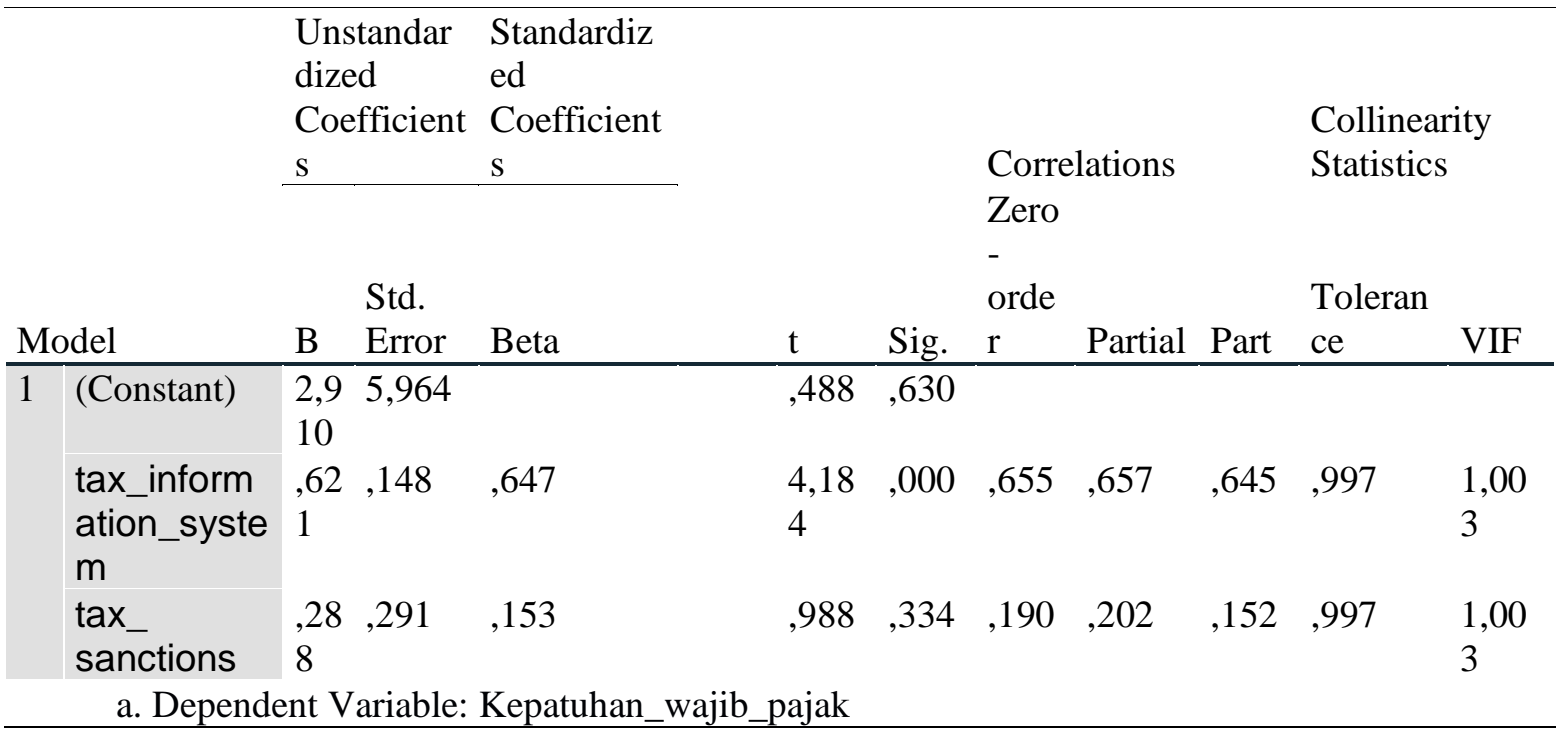

Source: Data processed, 2020

This multicolonierity test aims to test whether a regression model can correlate between independent (independent) variables, so a detection is carried out by testing the multicolonierity symptom. It can be assumed that multicolonierity states that variables must be free from multicolonierity symptoms. Multicolonierity testing is seen from the amount of VIF (Variance Inflation Factor) and Tolerance, therefore in this study the VIF value is used as an indicator of the presence or absence of multicolonierity between independent variables.

The multicolonierity test results of the independent variables $X 1$ and $X 2$ have a tolerance value of 0.997 , so it can be concluded that each variable has a tolerance value less than 0.10 . The VIF value calculation results also show the same thing, where the VIF value of each independent variable is 1.003 more than
10 , it can be concluded that there is no multicolonierity between the independent variables in the regression model

\section{Heteroscedasticity Test}

The heteroscedasticity test aims to test whether the regression model has an inequality of variance and residuals from one observation to another. Testing this assumption is done by looking at the scatter plot graph between the dependent variable (ZPRED) and its residual independent variable (SRESID). If there is no symptom of heteroscedasticity, the data points spread above and below or around the number 0 , the distribution of data points also forms a pattern, on the contrary, if it is in a regular pattern, it can be said that heteroscedasticity occurs. 


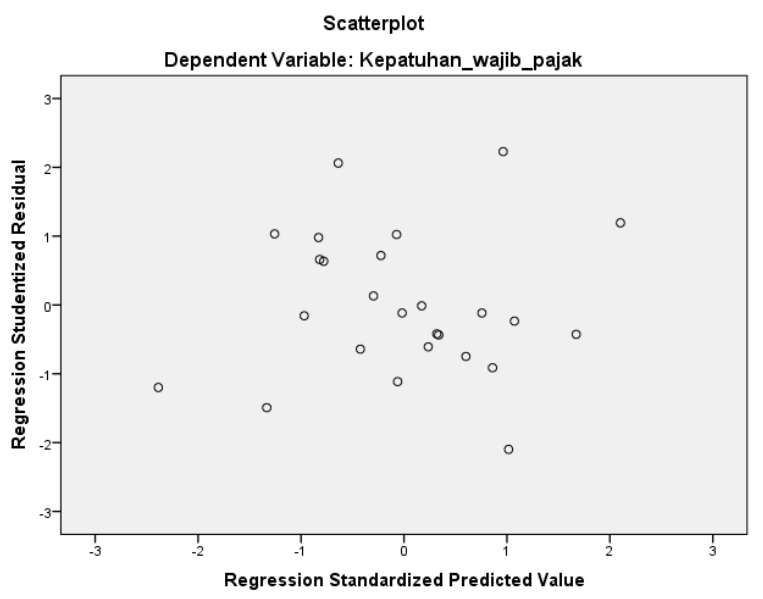

Figure 3: Heteroscedasticity test results

Based on the results of the heteroscedasticity test, the scatterplot graph illustrates the distribution of data points that spread evenly above and below the number 0 without any clear pattern, therefore it can be concluded that there is no heteroscedasticity in the regression model, so the regression model is feasible to use.

\section{Hypothesis testing} Multiple Linear Regression Analysis Hypothesis testing in hypothesis testing, the test tool used in this study is multiple linear regression equation analysis. From the calculation table using SPSS, the output and the multiple regression relationship equation are obtained.

Table 2: Multiple Linear Regression Test Results

\begin{tabular}{|c|c|c|c|c|c|c|}
\hline \multirow{2}{*}{\multicolumn{2}{|c|}{ Model }} & \multicolumn{2}{|c|}{$\begin{array}{l}\text { Unstandardized } \\
\text { Coefficients }\end{array}$} & \multirow{2}{*}{$\begin{array}{c}\text { Standardized } \\
\text { Coefficients } \\
\text { Beta } \\
\end{array}$} & \multirow[b]{2}{*}{$\mathrm{t}$} & \multirow[b]{2}{*}{ Sig. } \\
\hline & & B & Std. Error & & & \\
\hline \multirow[t]{3}{*}{1} & (constant) & 2,910 & 5,964 & & ,488 & 630 \\
\hline & $\begin{array}{l}\text { tax_informatio } \\
\text { n_system }\end{array}$ &, 621 & 148 & ,647 & 4,184 & ,000 \\
\hline & tax_sanctions & ,288 & 291 &, 153 & ,988 & ,334 \\
\hline
\end{tabular}

Source: processed data, 2020

The results of multiple linear regression tests are then entered into

$$
\begin{gathered}
Y=a+b_{1} X_{1}+b_{2} X_{2}+e \\
Y=2,910+0,621 X_{1}+0,288 X_{2}+e
\end{gathered}
$$

Based on this equation, the tax information system independent variable (X1) has an effect on taxpayer the multiple linear regression equation model with the following formulations: 
The constant value is 2,910 and is positive. This value indicates that the tax information system independent variable (X1), and tax sanctions (X2) are considered constant or do not change (value zero), the taxpayer compliance (Y) will be worth 2,910. The regression coefficient for the tax information system (X1) is 0.621 and is positive. This means that every change of a unit in the tax information system variable assuming the other variables remain, the taxpayer compliance changes by 3.198 in the same direction. The regression coefficient for the tax sanction variable (X2) is 0.288 and is positive. This means that every one-unit change in the tax sanction variable with the assumption that the other variables are fixed, the taxpayer compliance will experience a change of 3.198 in the same direction.

\section{Coefficient of Determination}

Measuring how far the model's ability to apply variations in the dependent variable is carried out by the coefficient of determination ( $R$ square).

Table 3: Results of the determination coefficient test

\begin{tabular}{|c|c|c|c|c|}
\hline Model & $\mathrm{R}$ & R Square & $\begin{array}{l}\text { Adjusted R } \\
\text { Square } \\
\end{array}$ & $\begin{array}{c}\text { Std. Error of the } \\
\text { Estimate }\end{array}$ \\
\hline 1 &, $673^{a}$ & ,453 & ,405 & 4,843 \\
\hline
\end{tabular}

a. Predictors: (Constant), Sanctions_Pax, Tax_Information_System

b. Dependent Variable: Taxpayer compliance

Source: processed data, 2020

The coefficient of determination test results show the coefficient value (multi $\mathrm{R})$ of 0.673 , this indicates that the closeness of the relationship between the independent variable of the tax information system (X1) and tax sanctions (X2) on the dependent variable taxpayer compliance $(\mathrm{Y})$ is $67.3 \%$. This shows the closeness of the relationship between tax information system and tax rates on taxpayer compliance is strong. The adjusted $R$ square value or the coefficient of determination is obtained at 0.453 . This value shows the magnitude of the influence of the independent variable on the dependent variable. So it can be seen that the effect of the independent variable on the dependent variable in this study is worth $45.3 \%$. This means that the variation of the $Y$ variable can be explained by the variation of the independent variable. While the remaining $(100 \%-45.3 \%)$ of $54.7 \%$ is explained by the influence of other variables not included in this study.

\section{Hypothesis Testing Results $F$ test (simultaneous)}

To find out whether the independent variables simultaneously have a significant effect on the dependent variable, the $\mathrm{F}$ test is carried out where in this case the $\mathrm{F}$ test is used to test the hypothesis whether the tax information system variables (X1) and tax sanctions (X2) simultaneously or jointly affect taxpayer compliance $(Y)$. the degree of confidence used is 0.05 . Where in this case if the value of the $F$ test calculation is greater than the $F$ value generated from the table, then an alternative hypothesis which states that the independent variables simultaneously have a significant effect on the dependent variable. 
Table 4. F Test Results (Simultaneous Test)

\begin{tabular}{llcrrrr}
\hline \multicolumn{2}{c}{ Model } & & Sum of & \multicolumn{4}{c}{ Mean } \\
Squares & df & Square & F & Sig. \\
\hline 1 & Regression & 446,182 & 2 & 223,091 & 9,510 &, $001^{\text {b }}$ \\
& Residual & 539,528 & 23 & 23,458 & & \\
& Total & 985,710 & 25 & & &
\end{tabular}

a. Dependent Variable: Taxpayer compliance

b. Predictors: (Constant), Tax Sanctions, Taxation Information Systems

Source: processed data, 2020

The results of this test show that the Fcount value is 9,510 with a significance value of 0.001 . F-count $>$ F-table with the number of samples $(n)=26$; number of independent variables $(k)=2$; significant tariff $\alpha=5 \%$, so that the Ftable value of 3.28 is obtained with the following equation: $\mathrm{F}$ table $=\mathrm{F}(\mathrm{k}: \mathrm{n}-\mathrm{k})=\mathrm{F}(2 ; 24)$ $=3.40$ The $F$-count value $>F$-table $(9,519>3.40)$ and the significance level is smaller than the distrust tariff $(0,000$ $<0.05)$. Based on these results it can be concluded that the variable (X1) tax information system and the second variable (X2) tax sanctions are assessed simultaneously as having a sig effect on variable $(\mathrm{Y})$ taxpayer compliance, so that the first hypothesis proposed can be accepted.
T test

The $t$ test is conducted to test the hypothesis whether the variable (X1) tax information system and variable (X2) tax sanctions partially affect the variable $(Y)$ taxpayer compliance with $5 \%$ freedom so that the possibility of a small disturbance. The number of research samples (n) was 26, the number of independent variables $(k)$, so that the $t$ table value was 1.174 using the following equation:

$\mathrm{t}$ table $=\mathrm{t}(\alpha ; n-\mathrm{k}-\mathrm{I})=\mathrm{t}(2 ; 23)+1,714$

Based on the results of the $t$ test, it shows that the results of the $t$ test statistical calculations of the independent variables are included in the regression model, here are the results and explanations of the above test results:

Table 5. T Test Results

\begin{tabular}{|c|c|c|c|c|c|c|}
\hline \multirow{2}{*}{\multicolumn{2}{|c|}{ Model }} & \multicolumn{2}{|c|}{$\begin{array}{c}\text { Unstandardized } \\
\text { Coefficients } \\
\text { Std. }\end{array}$} & \multirow{2}{*}{$\begin{array}{c}\text { Standardized } \\
\text { Coefficients } \\
\text { Beta }\end{array}$} & \multirow[b]{2}{*}{$\mathrm{t}$} & \multirow[b]{2}{*}{ Sig. } \\
\hline & & B & $\begin{array}{l}\text { Std. } \\
\text { Error }\end{array}$ & & & \\
\hline \multirow[t]{3}{*}{1} & (Constant) & 2,910 & 5,964 & & ,488 &, 630 \\
\hline & Tax_Information_System & 621 & ,148 & ,647 & 4,184 & 000 \\
\hline & Tax_Sanctions & ,288 & ,291 & , 153 & ,988 & ,334 \\
\hline
\end{tabular}

Source: processed data, 2020

The $t$ test on the independent variable of the tax information system (X1) with a count value of 5.077 is greater than the $t$ table value of 1.714 (4.184>1.714) and a significant value of
$0.000<0.05$. This indicates that partially the tax information system has a positive and significant impact on taxpayer compliance. Based on these results it can be concluded that the second 
hypothesis which states that the taxation information system has a partial and significant effect on taxpayer compliance is accepted. The t test on the independent variable of tax sanctions (X2) has a t value of $0.988<t$ table of 1.714 and a significant value of $0.288>$ 0.05 . The resulting tax sanctions are positive but have no effect, meaning that tax sanctions are not significant for taxpayer compliance, because they have a t-count value less than 0.05 , thus this value means that tax sanctions (X2) have no effect on taxpayer compliance. (Y). partial correlation value is 0.152 , the effect of tax sanctions on taxpayer compliance can be calculated as 0.152 $=0.001$ or $2.3 \%$ on taxpayer compliance. Based on these results, the second hypothesis ( $\mathrm{Ha}$ ) of this study where tax sanctions have no significant effect on taxpayer compliance is rejected.

\section{CONCLUSION}

From the results of this research that has been conducted regarding the effect of tax information systems and tax sanctions on taxpayer compliance, the following conclusions can be drawn: The Influence of Tax Information Systems and Tax Sanctions on Taxpayer Compliance Based on the results of the $F$ test, the tax information system ( $x 1$ ) and tax sanctions (X2) simultaneously affect taxpayer compliance $(Y)$. These results were obtained based on a questionnaire distributed to 26 respondents and based on the results of the $\mathrm{F}$ test performed, obtained $\mathrm{F}$ count> $f$ table and the significance level obtained is smaller than the significant level, namely 0.05 . From these results it means that the independent variable tax information system and tax sanctions simultaneously have a positive effect on the dependent variable taxpayer compliance, this proves that the first hypothesis can be accepted. The results of this study prove that synchronization between tax information systems and tax sanctions can increase taxpayer compliance in carrying out tax activities. This is evidenced by the answers of individual taxpayers who own the cafe, on average, know the tax information system and its benefits, but most of them do not understand or know the tax sanctions imposed on their business, thus indicating negligence in paying their taxes. thus an information system that facilitates and the existence of knowledge about The Influence of the Taxation Information System on Taxpayer Compliance The results of hypothesis testing using the t-test showed that the tax information system has a partial effect on taxpayer compliance with the results of the test on the independent variable tax information system (X1) has a t count of 5.077 the value is greater than the table value of $1.174(4.184>1,714)$ and is considered significant at $0,000<0.05$. This indicates that partially the tax information system has a positive and significant impact on taxpayer compliance. This illustrates that the use of appropriate, fast, inexpensive tax information technology is expected to encourage taxpayer compliance through various forms of reliable taxation services. It is believed that the existence of technology with a taxation system will increase the effectiveness and efficiency of tax management. This is in line with research conducted by Endang Satyawati (2017). Where the results of the research conducted, that the selfassessment system and tax information system affect tax compliance. This research is expected to contribute positively to the tax office and can be used as a reference for further research. This is also in line with research conducted by Alief Ramdhan (2017). Where, the test results show that there is no significant difference between the tax revenue before and after the tax information system, which means that the application of the tax information system does not significantly affect tax revenue. The Effect of Tax Sanctions on Taxpayer Compliance The test results 
on the second hypothesis on the test show that tax sanctions have no effect on taxpayer compliance where the t test on the independent variable tax sanctions (X2) has a t value of $0.988<t$ table of 1.714 and a significant value of $0.288>0.05$. The resulting tax sanctions are positive, it's just that the tax sanctions variable has no effect on taxpayer compliance with a significant value less than 0.05 , meaning that tax sanctions have a positive but insignificant effect on taxpayer compliance, thus this value means that tax sanctions (X2) has no effect on taxpayer compliance (Y). value correlation partial effect of tax sanctions on taxpayer compliance is $2.3 \%$ on taxpayer compliance. Based on these results, the $\mathrm{Ha}$ hypothesis of this study where tax sanctions have no positive effect on taxpayer compliance is rejected. The results of this study are in line with research conducted by Bahri Syaiful (2018) where the results of this study show that the quality of tax

\section{REFERENCES}

Alief Ramdan. (2017). "Pengaruh Sistem Informasi Perpajakan Terhadap Kepatuhan Wajib Pajak Dan Penerimaan Pajak Di Kantor Pelayanan Pajak Badan Dan Orang Asing Satu Menurut Wajib PajaK." Jurnal IImiah IImu Administrasi Volume 9,.

Bahri, Saiful. (2018). "Pengaruh Kualitas

Pelayanan Pajak, Pemahaman Peraturan Perpajakan Serta Sanksi Perpajakan Terhadap Kepatuhan Wajib Pajak (Pada Kantor Pajak Kpp Pratama Kota Banda Aceh)." Jurnal Perspektif Ekonomi Darussalam Vol 4 No 2.

Budiningsih. (2009). Belajar Dan Pembelajaran. jakarta: PT. Rineka Citra. services, understanding of tax regulations and tax sanctions simultaneously affect taxpayer compliance, but if seen partially, the quality of tax services and tax sanctions does not have a significant effect on taxpayer compliance. But the understanding of tax regulations has a significant effect on taxpayer compliance in the KPP Pratama area of Banda Aceh. Tax sanctions are important because with existing tax sanctions, tax collection can be done in an orderly manner. This is so that taxpayers do not neglect and can also prevent violations of taxation norms. The results of this research conducted on a partial test show that tax sanctions are still not able to make taxpayers obey to carry out their tax obligations. this could occur due to lack of knowledge regarding tax sanctions. By giving tax sanctions that are burdensome to taxpayers, it is hoped that it can provide a deterrent effect so as to create taxpayer compliance.

Direktorat Jendral Pajak, UndangUndang 16 Tahun (2009) Tentang Perubahan Ketiga atas Undangundang Nomor 6 tahun 1983 Tentang Ketentuan Umum dan Tata Cara Perpajakan

Direktorat Jendral Pajak, UndangUndang Nomor 28 Tahun (2007) tentang Perubahan Ketiga atas Undang-Undang Nomor 6 Tahun 1983 tentang Ketentuan Umum dan Tata Cara Perpajakan.

Erly Suandy. (2014). Hukum Pajak Edisi 6. jakarta: Salemba Empat.

Esti Rizqiana Asfa dan Wahyu Meiranto. (2017). "Pengaruh Sanksi Perpajakan, Pelayanan Fiskus, Pengetahuan Dan Pemahaman Perpajakan, Kesadaran Perpajakan Terhadap Kepatuhan Wajib Pajak." Diponegoro Journal Ofaccounting Vol 6 no 3. 
Ghozali imam. (2011). Aplikasi Analisis Multivariate Dengan Program IBM SPSS 19. 5th ed. semarang: Badan penerbit universitas Diponegoro.

Hardiningsih, Pancawati dan Nila Yulianawati. (2011). "Faktor-Faktor Yang Mempengaruhi Kemauan Membayar Pajak. Dinamika Keuangan Dan Perbankan." EJurnal Vol. 3, No.

Ir. Endar Sugiarto. (1996). Pengantar Akomodasi Dan Restoran. jakarta: PT. Gramedia pustaka utama.

Jatmaiko Agus Nugroho. (2006). "Pengaruh Sikap Wajib Pajak Pada Pelaksanaan Sanksi Denda, Pelayanan Fiskus Dan Kesadaran Perpajakan Terhadap Kepatuhan Wajib Pajak." Universitas Diponegoro. thesis.

Mardiasmo. (2011). Perpajakan. revisi 201. yogyakarta: Andi.

O'Brien, Marakas \&. (2016). Analisa Tata Sistem Informas/Tata Sutabri Edisi 1 . edited by Andy. yogyakarta.

Peraturan Direktur Jendral Pajak Nomor 160/pj/2006.https://perpajakan.ddtc .co.id/ . Di akses 29 Juli 2020

Puspa, Arum. (2012). "Pengaruh Kesadaran Wajib Pajak, Pelayanan Fiskus, Dan Sanksi Pajak Terhadap Kepatuhan Wajib Pajak Orang Pribadi Yang Melakukan Kegiatan Usaha Dan Pekerjaan Bebas: Studi Di Wilayah KPP Pratama Cilacap." Universitas Diponegoro, Skripsi.

Ramadhani Indah Sari, Dian Anita Nuswantara. (2017). "The Influence Of Tax Amnesty Benefit Perception To Taxpayer Compliance." Jurnal Dinamika
Akuntansi Vol. 9, No.

Satyawati, Endang dan Cahjono, Mardanung Patmo. (2017). "Pengaruh Self Assessment System Dan Sistem Informasi Perpajakan Terhadap Kepatuhan Wajib Pajak." JRAK Volume 13,.

Simanjuntak Timbul H. dan Mukhlis, Imam. (2012). Dimensi Perpajakan Dalam Pembangunan Ekonomi. jakarta: Raih asa sukses.

Siti Kurnia Rahayu. (2013). Perpajakan Indonesia: Konsep \& Aspek Formal. yogyakarta: Graha IImu.

Siti Masruroh dan Zulaikha. (2013). "Pengaruh Kemanfaaatan NPWP, Pemahaman Wajib Pajak, Kualitas Pelayanan, Sanksi Perpajakan Terhadap Kepatuhan Wajib Pajak (Studi Empiris Pada WPOP Di Kabupaten Tegal)." Diponegoro Journal Of Accounting Volume 2,.

Sugiyono. (2013). Metode Penelitian Pendidikan Pendekatan Kuantitatif, Kualitatif, Dan R\&D. Bandung: Alfa Beta.

Sugiyono. (2016). Metode Penelitian Kuantitatif, Kualitatif Dan R\&D. Bandung: PT Alfabet.

Undang-Undang Republik Indonesia Nomor 20 Tahun (2008) Tentang Usaha Mikro, Kecil dan Menengah dan Undang-Undang Republik Indonesia Nomor 21 Tahun 2008 tentangt Perbankan Syari'ah

Waluyo. (2014). Perpajakan Indonesia. Jakarta: Salemba Empat.

Yakub. (2012). Pengantar Sistem Informasi. yogyakarta: Graha IImu.

Zaenal Arifin. (2011). Penelitian Pendidikan. Bandung: PT Remaja Rosdakarya. 